\title{
Bilingual Method- A Solution for the Plethora of challenges present in a non-native Language
}

Classroom

\author{
Naheeda Begum
}

B.Sc., M.A., B.Ed, Post Graduate Teacher in English, Telangana Minority Residential School G 2, Mahabubnagar, Telangana, India neheedabegum786.nb@gmail.com

Abstract - The second Language teaching has witnessed unprecedented onslaughts of methods and trysts during the World War II. The War demanded quick and efficient mastering of target language by the soldiers that they can be well versed with the target language and can work their ways in the enemy territory. Soldiers needed to be equipped with the language that was spoken by their opponents in the battlefield, which has become as much important as their arsenal to fight the foe. Audio lingual method which is the resultant method of the efforts laid by the language teachers to teach the American soldiers concentrated on the language drills with the consequential replacement of the verbal components of the relevant phrases without any reverence to the first language. Audio Visual Method focused on the mechanistic approach of making the students repeat the phrased continuously as if they are practicing the drill in the ground. But the hiatus has remained in terms of expression of deep and profound thoughts in target language. Audio visual method which is also called the Army method failed to see the demand of the intricate language structure in expressing probing thoughts because the stringent time schedule in which the soldiers should learn the target langue was insufficient to equip them with all the paraphernalia of target language. It was just learning the langue in artificially controlled environment.

Besides the AV method there is another method which focuses on just using the target language ignoring the importance of mother tongue in second language acquisition that is the Direct Method which is popularized by Berlitz and Inlingua schools in 1970s and 1980s focus on subjecting the learner to the real life situation in language learning(Freeman). It is also called 'Natural method' because it caters to the mechanism of language acquisition rather than language leaning. Among the four skills of language use only the Spoken aspect of the language communication held prime over the other aspects like reading and writing in Direct method (Kumar). The underlying rules of grammar and syntax are taught indirectly rather than directly which had been a part of conventional teaching methodology. Bilingual method draws its inspiration from both Direct and AV methods in using its principles in teaching second language. My paper will deal with the propensity of using a method and to teach second language and raise the interest in the students to go further to develop language skills on their own as well.

Keywords-AV method, Direct method, GT method, Post method, Clutch or Tool.

\section{THE PRACTICALITY OF IMPOSING METHOD IN CLASSROOM}

For the teacher and for the material to be produced in the classroom, it has become a big challenge to finalize the method as the most suitable one to deliver the content effectively so that students can understand and acquire the language skills. The presence of various methods at hand usually creates a limbo situation, all the methods would wish run their course and appeal to the language teacher as equally important. But, still the hiatus exists between the theory and practicality of the situation. finally with experience only we can arrive at the conclusion that no method is perfectly suitable to the students to be authorized as single perfect method. Any method weather it is old or new shall limit the creativity of the teacher in imparting the language skills to the student and it shall not make the learner feel the learning process as burdensome. If joyful learning process is absent the learning process cannot take place with its full potential. 
Impracticality of selecting a single method as a perfect method:

As teaching tradition suggests, beginning from Grammar Translation method to the communicative approach all the methods and approaches vied with the partial aspects of the language teaching without addressing the complete demand of the scenario of language teaching. Direct method never thinks of using the mother tongue, using the mother tongue is barred and looked down upon as the inefficiency on the part of teacher and student as well. Suggestopedia or Silent way focuses on student centric teaching without going deep into the mechanics of psycholinguistics. Heterogeneousclassroomenvironments always make the teacher feel crippled when he/she inclined to use any single method for the entire schemata of instruction.

The following points to be kept in mind by the teacher while addressing the issue of imparting second language skills to the students of non native classroom.

They are..

i) Intention to mean

ii) Information Gap

iii) Personalization

iv) Unpredictability

v) Legitimacy

vi) Target Language Use

vii) Approach to Error

viii) Authenticity

ix) Speech Vs Writing

x) Practice Vs Real language

These issues to be handled effectively, in the arena of Post method, no single method can do justice. In Indian context where English is not the mother tongue and no intensive exposure is not possible to the English langue in gamut of rural urban divide, the Bilingual method will fruitfully come to aid the teacher in her mission of making the students move towards English language acquisition. Post colonial mentality of self pity self abnegation shall give way to the adoration of creativity irrespective which tool we are using weather it is a desi one alien one. The decolonizing the mind certainly starts with owning the own language but not by discarding it as if it is a sin.

\section{THE BILINGUAL METHOD}

$\mathrm{C} \mathbf{J}$ Dodson is the pioneer of the Bilingual method became famous during 1970s in academic circles. It favored the use of mother tongue in acquiring second language. It is against the hegemonic privileging the one language over the other. The colonial bent of mind which is still existing in the left over ideological frameworks of the mind lingers large which wish to hinder the process of giving importance to the use of mother tongue in teaching second language. The LAD (Language acquisition device) which is hypothecated by Noam Chomsky would become active by making the learner expose to the language mechanism(Trask). Bilingual method fills the gap which exists between theory and practicality of learning.

It is a Tool Not a Clutch:

Principles of bilingual method:

(a) Mother tongue makes the meaning of the words and phrases of target langue very clear to the learner.

(b) Teacher can easily create cultural context for the student so that he understand the assumption and can effectively put to use the target langue. Mother tongue can enable the students understand the context clearly.

(c) The time saved from creating the situations for teaching sentences and words of a foreign language can be used for giving more pattern practice to the students.(Tiwari)

The Native Classroom - Challenges and Avenues :

The experience of the teacher can bring about the following inferences while encountering the multi cultured heterogeneous classroom in Indian context.

i) Unlike western countries Indian classrooms are not homogeneous. Using the target language alone can create the problem of unintelligibility and it would become time consuming activity. Using the target langue 'only' would hamper the learning process of student which depends on natural acquisition.

ii) The mechanical drills as envisaged in AV method can only be successful to learn and master the basicpatterns of language skills but not properly suitable to deal with expression of profundity of language use. (Kumar)

iii) If the native tongue is not used, students would not understand the meaning of utterances in a complete manner because a teacher can impart the language skills by creating simulated situation but that context would become meaningful if it is created depending on the parameters of native culture and native living experience. .

John Haycarf (1978: 48) demonstrates that "the only way to teach the meaning of many abstract words is 
by creating a context or situation from which the students can they reduce the meaning." For example, if a teacher wants to teach the word "friend"eee hel she can pick characters from the class of students. Therefore, presenting new words through context requires the following considerations.(Oljira).

iv) Relevant grammatical structure can be understood effectively if the mother tongue is put to use in deciphering the patterns of target langue structures.

\section{CONCLUSION}

The importance of using the mother tongue shall not be neglected in teaching the target language. The identity of language shall not come from the racial privilege or economic strength of its users but from its use. the language identity politics shall come inside the classroom as classroom is the platform where all the pride and prejudices of one language over the other shall be gone with the replacement of equal identity and privilege as every language is a bank of knowledge it itself.

\section{REFERENCES}

[1] Drews, Elizabeth Monroe, 'The Effectiveness of Homogenous and Heterogeneous Ability Grouping', Michigan State university. 1968

[2] Freeman, Dianne Larsen, 'Techniques and Principles in Language Teaching'. Oxford University Press.London.2003

[3] Markandeya, Jodal Madhukar, 'A Critical Study of the Use of The Audio Visuals in Teaching English'. Pusthak Mahal. New Delhi. 1995

[4] Trask, Rober Lawrence, 'The Key Concepts in Language and Linguistics'. Rutledge Press. London.1999

[5] International Journal of Science and Research (IJSR) ISSN (Online): Volume 6 Issue 6, June 2017 'A Study on Problems of Vocabulary Teaching Techniques English Teachers Use in Holeta Primary Schools: Grade Seven in Focus' Dessalegn Oljira.

[6] Kumar, Rajinder, 'Teaching of English'. Lotus Press. New Delhi.2006

[7] Tiwari, Saket Raman, 'Teaching of English'. A P H publishing corporation. New Delhi. 2009 